\begin{tabular}{lllllllll}
\hline $\mathrm{M}$ & $\mathrm{A}$ & $\mathrm{T}$ & $\mathrm{E}$ & $\mathrm{R}$ & $\mathrm{I}$ & $\mathrm{A}$ & $\mathrm{E}$ & $\mathrm{Y}$
\end{tabular}

\title{
STRUKTURA WŁASNOŚCI ZIEMSKIEJ I JEJ DOCHODÓW W WOJEWÓDZTWIE KIJOWSKIM W 1789 R.
}

Konstytucja Sejmu Czteroletniego z 22 X 1788 r., powołująca stutysięczna armię ${ }^{1}$, niosła za sobą poważne konsekwencje w zakresie skarbowości. Wedle obliczeń Fryderyka Moszyńskiego, komisarza Komisji Skarbowej i posła na sejm z woj. bracławskiego, koszt wystawienia stutysięcznej armii wynosił około $48,5 \mathrm{mln}$ zł, przy ówczesnych dochodach skarbu na poziomie zaledwie $19,5 \mathrm{mln} \mathrm{z}^{2}$. Niezbędne sumy można było uzyskać poprzez podwyższenie istniejących podatków, uchwalenie szeregu dodatkowych mniejszych podatków lub poprzez uchwalenie jednego wielkiego podatku.

6 IV 1789 r. sejm uchwalił stały i powszechny podatek oblatowany pod nazwą Ofiara wieczysta Prowincjów obojga narodów na powiększenie sił krajowych ${ }^{3}$, zwany Ofiara 10 i 20 grosza. Obciążał on dochody z dóbr ziemskich w wysokości $10 \%$ z dóbr dziedzicznych i $20 \%$ z dóbr duchownych, przy zachowaniu dotychczasowego subsidium charitativum ${ }^{4}$. Szczegółowe postanowienia proceduralne oraz przepisy dotyczace wyliczania intraty, zasad zwolnienia z podatku i wybierania podatku uchwalono 30 maja w ustawie Sposób wynalezienia ofiary z dóbr ziemskich

\footnotetext{
${ }^{1}$ Volumina legum (dalej: VL), t. 9, Kraków 1889, s. 52.

${ }^{2}$ T. Korzon, Wewnętrzne dzieje Polski za Stanisława Augusta (1764-1794), t. 3, Kraków-Warszawa 1897, s. 247.

${ }^{3}$ VL, s. $73-74$.

${ }^{4}$ Była to dobrowolna ofiara duchowieństwa na potrzeby skarbu. Sejm jej formalnie nie uchwalił, ale przyjmował deklarację duchowieństwa do zapłaty określonej sumy. Ofiare płacono tytułem hiberny na potrzeby wojska, w zamian za co dobra duchowne były uwolnione od leż zimowych. W $1775 \mathrm{r}$. zniesiono hibernę, zamieniając ją na półpodymne z dóbr stołowych i królewszczyzn, co oznaczało, że płacono z nich 1/1/2 stawki podatku podymnego. Zachowano jednak subsidium charitativum; R. Rybarski, Skarbowość Polski w dobie rozbiorów, Kraków 1937, s. 218, 259, 260.
} 
i duchownych. W tej samej ustawie wyznaczono również komisarzy do oszacowania dochodów i wyliczenia podatku ${ }^{5}$. Ich prace trwały od połowy lipca do końca września.

Rzadko wykorzystywane w badaniach protokoły „Ofiary 10 i 20 grosza" stanowia doskonały materiał do badań zagadnień skarbowych, osadniczych, społeczno-gospodarczych, a zwłaszcza stosunków własnościowych w końcu XVIII w. Pomimo swej masowości i dostępności, do czasu zniszczenia podczas II wojny światowej przechowywanego w Archiwum Skarbowym w Warszawie ich największego zbioru, nie stały się podstawą szczegółowych analiz w tym zakresie $e^{6}$. Zasób protokołów nie został jednak zniszczony bezpowrotnie. Zgodnie z postanowieniem Sejmu Czteroletniego protokoły po zakończeniu prac i złożeniu podpisów przez komisarzy miały być w jednym egzemplarzu przekazane do grodu własnego, w drugim do Komisji Skarbowej ${ }^{7}$. Zniszczeniu uległy tylko te drugie, a protokoły oblatowane w grodach powinny się zachować, jeśli zachowały się księgi grodzkie. W Archiwum Państwowym w Poznaniu znajduja się niemal kompletnie protokoły dla Wielkopolski. Z oblat protokołów z ksiag grodzkich płockich korzystał Dariusz Główka $^{8}$, z ksiąg grodzkich łęczyckich Tadeusz Sobczak, Bohdan Baranowski i Julian Janczak ${ }^{9}$. Najprawdopodobniej protokoły „Ofiary 10 i 20 grosza" można odnaleźć w księgach innych grodów.

Przed II wojna światowa protokoły „Ofiary 10 i 20 grosza” stały się podstawą obszernych fragmentów dwóch prac poświęconych skarbowości. Były to Wewnętrzne dzieje Polski za Stanisława Augusta (1764-1794) Tadeusza Korzona, który tom trzeci swego dzieła poświęcił sprawom skarbowym oraz Skarbowość Polski w dobie rozbiorów Romana Rybarskiego ${ }^{10}$. Rybarski szczegółowo omówił ustawę, sposób szacowania intraty i porównał ja z innymi, podobnymi w treści dokumentami, m.in. cenami targowymi. Podkreślił niewysoki wymiar ofiary przyj-

\footnotetext{
${ }^{5}$ VL, s. 77-95; T. Korzon, dz. cyt., s. 236-237; R. Rybarski, dz. cyt., s. 274.

${ }^{6}$ W Archiwum Skarbowym w Warszawie przechowywano zespół składający się z przeszło 100 protokołów; zob. J. Stelmasiak, Protokóty ofiary 10-go i 20-go grosza (Korona), RDSG, t. 2, 1932-1933, s. 39-55.

${ }^{7}$ VL, s. 93.

${ }^{8}$ D. Główka, Protokoty „ofiary 10 i 20 grosza” jako źródto do badań stanu majatkowego duchowieństwa na przyktadzie powiatu płockiego, KH, t. 100, 1993, nr 3, s. 43-58.

${ }^{9}$ T. Sobczak, Zmiany $w$ stanie posiadania dóbr ziemskich $w$ województwie tęczyckim od XVI-XVIII w., RDSG, t. 17, 1955, s. 163-193; B. Baranowski, Wielkość folwarków szlacheckich $w$ Łęczyckiem $w$ XVIII wieku, ,Zeszyty Naukowe Uniwersytetu Łódzkiego", seria 1, 1957, z. 5, s. 51-65; J.K. Janczak, Zagadnienie ciężarów kościelnych we wsiach województwa tęczyckiego w XVI-XVIII w., „Rocznik Łódzki” 4, 1961, s. 43 n.

${ }^{10}$ T. Korzon, dz. cyt.; R. Rybarski, dz. cyt.
} 
mowany przez komisarzy. Podnoszone niedociagnięcia wynikały, jego zdaniem, z szybkiego tempa uchwalenia ustawy i improwizowanego aparatu skarbowego oraz nowości powszechnego podatku dochodowego w Rzeczypospolitej. Zaznaczył, że zaraz po zakończeniu prac komisji powiatowych stosowna deputacja sejmowa rozpoczęła prace nad poprawą ustawy ${ }^{11}$.

Przed wojną ukazał się również ważny artykuł Jerzego Stelmasiaka w całości poświęcony protokołom „Ofiary 10 i 20 grosza”. Autor skupił się w nim na analizie elementów treści i dokładności rejestrów podatkowych, podkreślając ich dużą wartość badawczą ${ }^{12}$. Po wojnie staraniem Mariana Miki zostały opublikowane protokoły wielkopolskie w części dotyczącej Poznania i dekanatu poznańskiego ${ }^{13}$. Ukazały się także artykuły Juliana Janczaka i Dariusza Główki poświęcone dobrom kościelnym $^{14}$, Bohdana Baranowskiego - poświęcone dobrom szlacheckim ${ }^{15}$ oraz Tadeusza Sobczaka, który na podstawie szesnastowiecznych rejestrów poborowych, protokołów „Ofiary 10 i 20 grosza” i taryfy podymnego z 1790 r. przeanalizował strukturę i zmiany własności w woj. łęczyc$\mathrm{kim}^{16}$. Kwestia tego podatku pojawia się również na kanwie szerszych rozważań dotyczących finansów i organów państwa w drugiej połowie XVIII w. ${ }^{17}$ Nie wnosza one jednak wiele w zakresie przygotowywania, treści i wartości protokołów, pracy komisarzy i wybierania podatku.

Podstawa niniejszej analizy jest osiemnastowieczny sumariusz protokołów „Ofiary 10 i 20 grosza” trzech powiatów wchodzacych w skład woj. kijowskiego ${ }^{18}$ oraz przeprowadzona dla tego samego okresu lustracja

${ }^{11}$ R. Rybarski, dz. cyt., s. 329 n.

12 J. Stelmasiak, dz. cyt.

${ }^{13}$ Ofiara na wojsko $z$ dóbr ziemskich $i$ duchownych (1 VII 1789). Dekanat poznański, w: Opisy i lustracje Poznania z XVI-XVIII wieku, przyg. do druku M.J. Mika, Poznań 1960, s. 306-323.

14 J.K. Janczak, dz. cyt., s. 31-49; D. Główka, dz. cyt., s. 43-58.

${ }^{15}$ B. Baranowski, dz. cyt., s. 51-65.

${ }^{16}$ T. Sobczak, dz. cyt., s. 163-193.

${ }^{17}$ M. Drozdowski, Podstawy finansowe działalności państwowej w Polsce 1764-1793. Dziatalność budżetowa Sejmu Rzeczypospolitej w czasach panowania Stanistawa Augusta Poniatowskiego, Warszawa-Poznań 1975, s. 137 n.; J. Gordziejew, Komisje Porzadkowe Cywilno-Wojskowe w Wielkim Księstwie Litewskim w okresie Sejmu Czteroletniego (1789-1792), Kraków 2010, s. 252-254.

${ }^{18}$ Biblioteka Zakładu Narodowego im. Ossolińskich, Dział Rękopisów (dalej: Bibl. ZNiO), rkps 500/III, Protokół ofiary 10 i 20 grosza województwa kijowskiego, s. 1-90. Kwerenda przeprowadzona w Centralnym Państwowym Archiwum Historycznym Ukrainy w Kijowie wykazała, że nie zachowały się protokoły, które powinny zostać oblatowane w księgach grodzkich. Do czasów współczesnych z osiemnastowiecznych ksiąg grodzkich dotrwały jedynie księgi żytomierskie i kijowskie. W księgach żyto- 
królewszczyzn tegoż województwa ${ }^{19}$. Wykorzystanie tych dwóch dokumentów umożliwia pełną analizę struktury własności ziemskiej województwa, obejmująca dobra szlacheckie, duchowne i królewskie.

Sumariusz jest poszytem o wymiarach $23 \times 36 \mathrm{~cm}, \mathrm{z}$ pozłoconymi brzegami kart, oprawiony wraz z kilkudziesięcioma innymi dokumentami pochodzacymi głównie z drugiej połowy XVIII w. oraz kilkoma z pierwszej połowy XVIII i XIX w. Sa wśród nich również osiemnastoi dziewiętnastowieczne druki. Dokumenty te zostały oprawione w jedna całość prawdopodobnie pod koniec XIX lub na początku XX w. Tekst protokołu został sporządzony przez jednego pisarza czytelnym i bardzo starannym pismem. Jest to odpis trzech protokołów powiatowych zebranych w jeden dokument przez nieznanego z nazwiska kopistę i zatytułowany Protokołem ofiary 10 i 20 grosza województwa kijowskiego. Autor odpisu rozpoczał pracę od pow. kijowskiego, o czym świadczy nie tylko układ geograficzny dokumentu, ale również to, że otwierający protokół opis czynności komisarzy dotyczy wyłącznie komisji tego właśnie powiatu. Dowodzi tego również lista komisarzy, wymienionych w konstytucji sejmowej przy pow. kijowskim oraz wykaz terminów czynności komisarskich planowanych do przeprowadzenia w kolejnych parafiach - wymieniono wyłącznie parafie leżące w pow. kijowskim. Pod dokumentem nie zamieszczono żadnych podpisów ani dat umożliwiajacych ustalenie czasu powstania i autorstwa protokołu. Dokument mógł powstać w końcu 1789 r. lub na początku lat dziewięćdziesiątych, na co wskazuje inne źródło - taryfa dymów pow. kijowskiego z 1790 r., sporządzona tym samym pismem co sumariusz ${ }^{20}$.

Wiarygodność protokołów „Ofiary 10 i 20 grosza” woj. kijowskiego, ze względu na brak materiału porównawczego, jest trudna do oceny. O ich wysokiej próbie moga świadczyć dołączane przez liczne komisje tabele wsi włączonych do protokołów, a które nie figurowały w taryfach wcześniejszych podatków. Takie tabele do Komisji Skarbowej

mierskich z 1789 r. nie znalazłem oblaty protokołu tego powiatu, ksiag kijowskich nie zdołałem przejrzeć. Kwerendę utrudnia umieszczenie w jednym ciagu sygnaturowym wszystkich serii ksiag bez ich zaznaczenia. Stąd badacz zmuszony jest zamówić kilka ksiag dotyczacych jednego roku, co przy ograniczonym czasie, ograniczeniu liczby wydawanych, zmikrofilmowanych jednostek do pięciu i ograniczonej liczbie czytników nie pozwoliło przejrzeć mi wszystkich ksiag, zwłaszcza że dla pow. kijowskiego aż 13 ksiag zawiera wpisy z $1789 \mathrm{r}$.

${ }^{19}$ AGAD, Archiwum Skarbu Koronnego (dalej: ASK), oddział XLVI, sygn. 4, Lustracja królewszczyzn województwa kijowskiego, 1789.

${ }^{20}$ Centralne Państwowe Archiwum Historyczne Ukrainy w Kijowie, fond 8, Komisja porządkowa cywilno-wojskowa powiatu żytomierskiego, opys 1, sprawa 8 . 
nadesłały m.in. komisje pow. owruckiego i kijowskiego ${ }^{21}$. Kierując się tymi przekazami i zdaniem przedwojennego znawcy tematu, Jerzego Stelmasiaka, przynajmniej w zakresie wiarygodności rejestracji miast i wsi protokoły „Ofiary 10 i 20 grosza” należy ocenić wysoko, znacznie wyżej niż taryfy podymnego. Słabiej wypadaja w zakresie oszacowania dochodów dóbr. Komisje tylko wyjątkowo miały bezpośrednio lustrować dobra duchowne i szlacheckie. Brak realnej kontroli „oświadczeń o dochodach" musiał prowadzić do zaniżania dochodów. O ile w wypadku oszacowania dochodowości dóbr można mieć zastrzeżenia, to w przypadku innych zagadnień stanowią one pierwszorzędny materiał. Dotyczy to przede wszystkim struktury własnościowej, parafialnej i w ograniczonym zakresie dochodowej końca XVIII w.

Przedmiotem opodatkowania były „stałe i pewne intraty”, czyli dochody z ziemi i inne przychody z gospodarstwa w dobrach szlacheckich, duchownych i mieszczańskich. Podstawą oceny dochodu miały być inwentarze lub - gdyby te się nie zachowały - inne wykazy przychodów z ostatnich trzech lat. Dopuszczano również możliwość przedstawienia wykazów z dwóch ostatnich lat, gdyby nie było 3-letnich. Z inwentarzy i regestrów miał być wyciagnięty średni dochód jednoroczny.

Z dóbr dziedzicznych i duchownych od opodatkowania wyłączono dziesięcinę i meszne płacone na rzecz Kościoła, ponieważ duchowieństwo było zobowiązane podać je w swoich dochodach. Podobnie $\mathrm{z}$ intrat dóbr dziedzicznych powinny być wyłączone sumy czynszowe i zapisy wieczyste na rzecz Kościoła zabezpieczone na dobrach, a potrącone z dochodów duchownych. Natomiast z dochodów dziedzicznych nie wyłączono zapisanych na Kościół sum wyderkafowych ${ }^{22}$.

Z opłacania ofiary wieczystej zwolniono szlachtę nieposiadającą poddanych i wysiewająca do 10 korców zboża. Od podatku zwolniono również fundusze na seminaria diecezjalne służące edukacji księży świeckich, fundusze wikariuszy i misjonarzy „pięćset złotych tylko na osobę dochodu mające", szpitale dla podrzutków, chorych i ubogich przeznaczające cały dochód na ich utrzymanie, fundusze i konwikty ubogich studentów oraz plebanów obu obrządków bez dziesięciny, jakichkolwiek

${ }^{21}$ J. Stelmasiak, dz. cyt., s. 43.

${ }^{22}$ VL, pkt. 6, 11 ustawy, s. 93, 94. Wyderkaf to transakcja kredytowa, w której pożyczkę kapitału na procent lub pod zastaw zastapiono sprzedażą nieruchomości z możliwościa jej odkupienia po zwróceniu przez sprzedawcę ceny kupna. Obowiązywały przy tym, w zależności od rodzaju umowy, różne terminy wykupu; B. Lesiński, Wyderek czyli sprzedaż nieruchomości z prawem odkupu $w$ prawie polskim od XV do XVII wieku, CPH, t. 28, z. 1, 1976, s. 29-30, 49 n. 
sum i poddanych ${ }^{23}$ oraz mieszczan w województwach koronnych, którzy posiadali grunty mniejsze niż pół włóki ${ }^{24}$. Niższy, ziemiański podatek mieli opłacać plebani mający curam animarum, którzy nie mieli pewnej i stałej intraty ponad 2 tys. zł; klasztory, które miały tylko 2 tys. zł dochodu na całe zgromadzenie; konwenty utrzymujące swoim kosztem szkoły publiczne mające co najmniej trzech profesorów, aprobowane przez Komisję Edukacji; zgromadzenia zakonne, które zostały powołane w celu edukacji publicznej ${ }^{25}$.

Ofiara za rok 1789 miała być zapłacona w racie wrześniowej, która sejm przedłużył do końca października tego roku. W kolejnych latach miała być płacona w dwóch ratach: styczniowej i czerwcowej ${ }^{26}$, co zmieniało dotychczasowe zwyczaje, według których podatki płacono w marcu i wrześniu.

Na potrzeby analizy lokalnej struktury własności przyjmuję klasyczny podział na własność królewska, duchowną i szlachecką ${ }^{27}$, z zaznaczeniem różnorodności majątkowej szlachty wedle zaproponowanego przez Włodzimierza Dworzaczka podziału na: magnaterię (powyżej 20 wsi), szlachtę bogatą (11-20 wsi), zamożną (6-10 wsi), średnią (1-5 wsi) oraz drobną (poniżej $1 \mathrm{wsi})^{28}$.

Analiza struktury własności woj. kijowskiego, z powodu występowania wielu majątków cząstkowych oraz różnej wielkości niedziałów, nastręcza wielu problemów. Na przykład 138 miast i wsi miało dwóch lub więcej właścicieli. W wypadku znacznie rozdrobnionych wsi autor sumariusza nie wymienił właścicieli wszystkich cząstek, ograniczając się do zapisania sumarycznego dochodu dla całej wsi. Jeśli zaznaczał majątki cząstkowe, to najczęściej ograniczał się do zapisu dwóch lub trzech czastek, często odnotowując przy nich nazwisko w liczbie mnogiej, co również uniemożliwia określenia liczby majątków. W związku z tym mówiąc $\mathrm{w}$ dalszej części artykułu o strukturze własności szlacheckiej, w wypadku majątków cząstkowych ograniczam się tylko do podania liczby wsi należących do tej grupy właścicieli ziemskich. Stąd też liczba majątków pozostaje niepełna. Kolejnym problemem są liczne

${ }^{23}$ VL, s. 73.

${ }^{24}$ Mieszczanie w Wielkim Księstwie Litewskim płacili osobny podatek po skasowanych magdeburianach; tamże, s. 94.

${ }^{25}$ Tamże, s. 73.

26 Tamże, s. 95.

${ }^{27}$ Pomijam tu własność miejską niewystępująca w woj. kijowskim. Natomiast grunty mieszczańskie w granicach miast królewskich nie zostały ujęte w sumariuszu.

${ }^{28}$ W. Dworzaczek, Sktad społeczny wielkopolskiej reprezentacji sejmowej w latach 1572-1655, „Roczniki Historyczne” 23, 1957, s. 295-296. 
majątki złożone z kilku nieznanej wielkości cząstek w różnych wsiach lub z jednej wsi i kilku cząstek. Przy nich trudno rozstrzygać, czy mamy do czynienia z własnościa cząstkowa, czy już z jedno-, czy nawet kilkuwioskową. W takich sytuacjach majątki złożone z pięciu i więcej cząstek traktuję jako własność jednowioskowa, a poniżej pięciu cząstek - jak własność cząstkowa.

Posiadanie jednej wsi lub miasta przez dwóch lub więcej właścicieli należących do różnych typów własności prowadzi do wielokrotnego zliczania tej samej miejscowości przy sumarycznych zestawieniach. Jeżeli informacja o liczbie osad dotyczy ogółu danej kategorii majątkowej, to miejscowości należące do kilku właścicieli zaliczonych do tej samej kategorii majatkowej będą liczone jako cała osada, ale w zestawieniach dotyczących wielkości poszczególnych majątków w tej samej kategorii - jako osobne części przy poszczególnych właścicielach.

Problemem są też wsie lub części wsi, przy których właściciela zaznaczono tylko nazwiskiem w liczbie mnogiej, co można oznaczać jeden majątek w posiadaniu kilku osób (najczęściej małżeństwa lub rodzeństwa) lub własność cząstkowa.

Kolejnym problemem były wsie i miasta w częściach należących do różnych typów właścicieli (król, szlachcic, Kościół). W tabeli 1, w której przedstawiono liczbę wsi i miast $\mathrm{w}$ trzech powiatach województwa z zaznaczeniem typu własności, jako wsie i miasta w częściach traktuję te miejscowości, które należały np. w części do starostwa, a w części do szlachcica lub Kościoła. Problemem w tym wypadku jest to, że na 27 takich wsi i miast aż dla 11 odnalazłem w „Ofierze 10 i 20 grosza” tylko jedna część. Druga lub kolejne zostały, zapewne przez nieuwagę, pominięte przez autorów tego dokumentu. Jako miasta w częściach traktuję także te, w których znajdowały się jurydyki, zarówno duchowne, jak i szlacheckie.

W 1789 r. na terenie woj. kijowskiego istniało 101 miast i miasteczek oraz 1787 osad wiejskich (wsi, słobód, futorów i rudni), z czego w pow. kijowskim 57 miast i miasteczek oraz 891 osad wiejskich, w pow. żytomierskim 29 miast i miasteczek oraz 502 osad wiejskich, a w pow. owruckim 10 miast i miasteczek oraz 394 osad wiejskich. Komisarze zaznaczyli właścicieli przy niemal wszystkich miejscowościach, pomijając ich przy trzech miastach, czastce miasta i 67 wsiach, leżących głównie w pow. żytomierskim. Brak informacji o właścicielach dotyczył głównie miejscowości leżących w granicach dawnej ordynacji ostrogskiej, przy których, poza 2 wsiami, zaznaczono nazwisko zastawnika, dzierżawcy lub dożywotnika. 
Tabela 1. Liczba miast i wsi w zależności od typu własności w poszczególnych powiatach woj. kijowskiego w 1789 r. ${ }^{29}$

\begin{tabular}{l|l|r|r|r|r|r}
\hline \multirow{2}{*}{ Powiat } & \multicolumn{1}{c|}{$\begin{array}{c}\text { Typ } \\
\text { własności }\end{array}$} & $\begin{array}{c}\text { Liczba } \\
\text { miast }\end{array}$ & $\begin{array}{c}\text { Liczba } \\
\text { wsi }\end{array}$ & $\begin{array}{c}\text { Części na- } \\
\text { leżáce do } \\
\text { różnch } \\
\text { typów } \\
\text { wlasności }\end{array}$ & $\begin{array}{c}\text { Razem } \\
\text { Liczba } \\
\text { bez- } \\
\text { względna }\end{array}$ & $\%$ \\
\hline kijowski & szlachecka & 36 & 627 & 7 & 670 & 69,9 \\
& królewska & 18 & 202 & 4 & 224 & 23,4 \\
& duchowna & 1 & 59 & 4 & 64 & 6,7 \\
& razem & 55 & 888 & 15 & 958 & 100 \\
\hline owrucki & szlachecka & 9 & 331 & 10 & 350 & 83,6 \\
& królewska & - & 7 & 2 & 9 & 2,2 \\
& duchowna & - & 53 & 6 & 59 & 14,2 \\
& razem & 9 & 391 & 18 & 418 & 100 \\
\hline \multirow{2}{*}{ żytomierskinnyyyyyy} & szlachecka & 21 & 459 & 6 & 486 & 90,9 \\
& królewska & - & 11 & 1 & 12 & 2,2 \\
& duchowna & 1 & 31 & 5 & 37 & 6,9 \\
& razem & 22 & 501 & 12 & 535 & 100 \\
\hline razem & szlachecka & 66 & 1417 & 23 & 1506 & 78,8 \\
& królewska & 18 & 220 & 7 & 245 & 12,8 \\
& duchowna & 2 & 143 & 15 & 160 & 8,4 \\
& razem & 86 & 1780 & 45 & 1911 & 100 \\
\hline
\end{tabular}

Dobra królewskie. Liczba wsi i miast królewskich w woj. kijowskim została ustalona na podstawie lustracji królewszczyzn z $1789 \mathrm{r} .{ }^{30}$ W tym roku na terenie województwa odnotowano 219 wsi i 4 części, 20 miast i 3 części królewskie, co stanowiło 12,8\% ogółu miejscowości. Wśród 3 miast czastkowych znalazły się miasta grodowe Żytomierz i Owrucz, co wynika z zaznaczonego wyżej traktowania jurydyk jako cząstki, którymi w rzeczywistości były.

${ }^{29}$ Miasta i wsie, których części należały do różnego typu własności, zostały zakwalifikowane do kolumny „Części należące do różnych typów własności”, a podstawą obliczenia była cząstka, a nie całe miasto lub wieś, w związku z tym liczone są dwu- lub trzykrotnie. AGAD, ASK, oddział XLVI, sygn. 4, Lustracja królewszczyzn województwa kijowskiego 1789; Bibl. ZNiO, rkps 500/III, Protokół ofiary 10 i 20 grosza województwa kijowskiego, s. 1-90.

${ }^{30}$ AGAD, ASK, oddział XLVI, sygn. 4, Lustracja królewszczyzn województwa kijowskiego, 1789; Archiv Jugo-Zapadnoj Rosii izdavajemyj kommissjeju dla rozbora drevnich aktov (dalej: AJZR), cz. 7, t. 3, Kijev 1905, s. 199-596. 
Większość dóbr królewskich Kijowszczyzny leżała w pow. kijowskim (224 wsie i miasta - 91,7\%), głównie w jego południowo-wschodniej części, przy granicy z Rosja. Pozostałe królewszczyzny w województwie to starostwa grodowe żytomierskie (11 wsi i miasto) i owruckie (6 wsi, część wsi i miasto) $^{31}$.

Królewszczyzny woj. kijowskiego znajdowały się w rękach 16 dzierżawców, którzy, poza jednym wypadkiem, dzierżyli po jednym starostwie. Większość pochodziła spoza województwa, zaledwie pięciu z nich posiadało tu dobra dziedziczne. Potentatem, jeśli chodzi o liczbę i wielkość posiadanych starostw, był Stanisław Poniatowski, podskarbi wielki Wielkiego Księstwa Litewskiego, dzierżący starostwa kaniowskie, bohusławskie, korsuńskie i sienickie, na które składały się 3 miasta i 108 wsi $\left(46,1 \%\right.$ królewszczyzn) ${ }^{32}$. Poniatowski posiadał również dobra dziedziczne w pow. kijowskim, złożone z 17 wsi i miasta. Starostwo czehryńskie (3 miasta i 35 wsi) posiadał Antoni Jabłonowski, kasztelan krakowski, który ponadto miał w woj. kijowskim jeszcze majątek dziedziczny (miasto i 19 wsi); czerkaskie (3 miasta i 17 wsi) - Hieronim Sanguszko, wojewoda wołyński; romanowskie (2 miasta i 11 wsi) - książę Józef Lubomirski; grodowe żytomierskie (miasto i 10 wsi) Kajetan Iliński, posiadający również 12 wsi w pow. żytomierskim; taraszczańskie (miasto i 8 wsi) - Mikołaj Piastowski; grodowe owruckie (miasto, 6 wsi i część wsi) oraz wieś Weresy w pow. żytomierskim Jan Stecki, który posiadał również miasto i 25 wsi w pow. owruckim i żytomierskim; niechworoskie (miasto i 4 wsie) - Ignacy i Marianna z Rudzińskich Kaniewscy, stolnikowie różańscy, posiadający ponadto wieś w pow. kijowskim; kahorlickie (5 wsi) - Jan Amor hrabia Tarnowski; hermanowskie (4 wsie i 1 część) - Kasper Dąbrowski; rożowskie (miasto i 4 wsie) - Ignacy Cetner, wojewoda bełski; taborowskie

${ }^{31}$ Liczba wsi należących do starostwa owruckiego podana w lustracji z 1789 r.jest niekompletna. Lustracja pow. owruckiego z 1765 r. wymienia Owrucz i 14 wsi; por. AGAD, ASK, oddział XLVI, sygn. 2, Lustracja powiatu owruckiego woj. kijowskiego, 1765.

${ }^{32}$ Starostwa korsuńskie i bohusławskie obok białocerkiewskiego i chmielnickiego na sejmie 1773-1775 r. Rzeczpospolita w dowód wdzięczności oddała na własność królowi Stanisławowi Augustowi Poniatowskiemu i jego sukcesorom. W 1777 r. starostwa kaniowskie i bohusławskie król Stanisław August podarował swojemu bratankowi Stanisławowi Poniatowskiemu. Lustratorowie zauważaja, że należy z nich zapłacić 10 gr, a nie podwójną kwartę, jak w wypadku królewszczyzn. Starostwo białocerkiewskie, podarowane przez króla Franciszkowi Ksaweremu Branickiemu w 1774 r., zostało obciążone jak dobra dziedziczne. Starostwo chmielnickie leżało w woj. podolskim; AGAD, ASK, oddział XLVI, sygn. 4, Lustracja królewszczyzn województwa kijowskiego, 1789; Polski stownik biograficzny, t. 27, Wrocław-Warszawa-Kraków 1982, s. 482; tamże, t. 2, Kraków 1936, s. 399. 
(miasto i 2 wsie) - Katarzyna z Rostkowskich Cyryna; szawuliskie (miasto i 2 wsie) - Ludwika Bierzyńska z Ponińskich, kasztelanowa żytomierska, posiadająca również 4 wsie i miasto w pow. kijowskim; dymirskie (miasto i wieś) - Kajetan Potocki, który dzierżawił je Kajetanowi Golejowskiemu; część starostwa zwinogrodzkiego (miasto) - Salomea z Brzozowskich Sołtykowa; starostwo szołomeckie (2 wsie) - Andrzej Komar, posiadający również 6 wsi i 2 cząstki w pow. owruckim i żytomierskim.

Dobra kościelne. Na dobra duchowne w woj. kijowskim składały się 2 całe i część miasta, 12 jurydyk w 10 miastach, 143 wsie i 4 części wsi, skupione w 24 różnej wielkości majątkach. Wsie i miasta leżące w dobrach kościelnych stanowiły 8,4\% osad województwa. Najwięcej było ich w pow. kijowskim (62) i owruckim (58), ale najwyższy odsetek dóbr duchownych widoczny był w pow. owruckim, w którym stanowiły one $14,2 \%$ miejscowości. W pow. żytomierskim i kijowskim dobra kościelne stanowiły odpowiednio 6,9 i $6,7 \%$ ogółu wsi i miast.

Największy majątek posiadała metropolia kijowska, na który składało się miasto i 67 wsi leżących we wszystkich trzech powiatach. Włości metropolii stanowiły $42,4 \%$ dóbr kościelnych w województwie. Wsie spisano w jednym ciagu z pominięciem administracji ekonomicznej i przynależności parafialnej, przez co nie można stwierdzić, czy stanowiły one zwarte kompleksy dóbr ${ }^{33}$. Kolejnym pod względem wielkości majątkiem kościelnym był klucz fastowski, będący uposażeniem biskupa kijowskiego Kacpra Kazimierza Cieciszowskiego. W jego skład wchodziło miasto i 22 wsie w pow. kijowskim. Większymi dobrami dysponowały również bazylianki koreckie (7 wsi i 3 części w pow. owruckim) i bazylianie owruccy, posiadajaccy jurydykę w Owruczu oraz 6 całych i część wsi w tymże powiecie. Być może byli również właścicielami 12 wsi, przy których zapisano jedynie „opactwo owruckie”, pomijając informację co do konwentu ${ }^{34}$. Do większych majątków można zaliczyć także posiadłości probostwa wielednickiego (miasto, 3 wsie i cząstka w pow. owruckim), dominikanów czarnobylskich (4 wsie w pow. owruckim), karmelitów berdyczowskich (jurydyka w Lubarze i 2 wsie w pow. żytomierskim), parafię chabeńską (jurydyka w Chabnem i 2 wsie w pow. żytomierskim) i nieokreślonych co do siedziby bazylianów (jurydyka w Lubarze, futor i część wsi w pow. żytomierskim). Pozostałe dobra to majątki dwuwioskowe lub złożone $\mathrm{z}$ wsi i części wsi (2), jednowioskowe (9) bądź cząstkowe (3).

${ }^{33}$ Komisarze sporządzający protokół najczęściej pomijali informację o organizacji ekonomicznej większych dóbr duchownych.

${ }_{34}$ Bardziej prawdopodobne, że byli to dominikanie posiadający w Owruczu klasztor i kościół parafialny. 
Dobra dziedziczne. Własność szlachecka w woj. kijowskim obejmowała 1506 wsi i miast, w tym 66 miast i 11 części miast, 1417 wsi i 12 części wsi. Własność szlachecka stanowiła 78,8\% dóbr ziemskich województwa (zob. tab. 1). W protokole odnotowano 267 majątków różniących się znacząco stanem posiadania oraz 69 wsi lub części wsi posiadanych przez najczęściej niewymienianą z nazwiska szlachtę czastkowa.

W 1789 r. na terenie województwa istniało 11 majątków (4,1\%), które składały się z ponad 20 miejscowości. W ich granicach leżało 518 całych wsi i miast oraz 11 czastek, co stanowiło 33,9\% własności szlacheckiej.

Największym majątkiem dysponował Franciszek Ksawery Branicki, hetman wielki koronny, w którego posiadaniu znajdowały się 4 miasta i 182 wsie. Jego rozległe włości w całości leżały w zachodniej części pow. kijowskiego, tworząc tam zwarty kompleks dóbr obejmujący całe cztery parafie: białocerkiewską (43), stawiską (83), lisiańską (31), rokitiańską (25) i niewielką część wasylowskiej (4).

Trzykrotnie mniejszym pod względem wielkości majątkiem były niedzielne włości Rokickich, składające się z miasta, 69 wsi i jednej części. Całość dóbr, poza 3 wsiami, leżała w parafii ostrohladowickiej, w północnej części pow. owruckiego, przy granicy z Litwa. Kolejnym, pod względem wielkości, właścicielem ziemskim byli wspólnie zarządzający dobrami bracia Józef, Wacław i Aleksander Chodkiewiczowie, synowie Jana Mikołaja, starosty żmudzkiego, i Ludwiki z Rzewuskich. Na majątek Chodkiewiczów składało się miasto Czarnobyl oraz 48 całych i 3 cząstki wsi. Całość dóbr skupiona była w kluczu czarnobylskim leżącym w parafii czarnobylskiej, we wschodniej części pow. owruckiego.

Pozostałe dobra magnackie były już wyraźnie mniejsze. Jan Stecki, starosta owrucki, posiadał miasto, 31 wsi i 4 cząstki leżące na pograniczu pow. owruckiego i żytmierskiego; Prot Potocki, starościc guzowski, posiadał w pow. kijowskim 2 miasta, 27 wsi i część wsi; Jan Nepomucen Iliński, starosta cudnowski - klucz kureński w pow. żytomierskim (miasto i $27 \mathrm{wsi}$ ); nieznany z imienia i urzędu Prozor - 2 miasta i 24 wsie leżące w parafii ostrohladowickiej, na północy pow. owruckiego; Szczęsny Czacki, podczaszy wielki koronny (do 1784) - miasto i 22 wsie w pow. kijowskim; bracia Damian, Jakub, Józef, Michał i Tadeusz Pawszowie, podkomorzyce owruccy - 2 miasta, 22 wsie i 16 części wsi leżących na pograniczu pow. owruckiego i żytomierskiego; Kajetan Rościszewski, dziekan katedry kijowskiej - miasto i 20 wsi w pow. kijowskim; a Grigorij Potiomkin, feldmarszałek wojsk rosyjskich - 21 wsi w pow. kijowskim.

Do magnaterii należy jeszcze doliczyć trzy majątki wspomnianych wcześniej przedstawicieli zamożnej szlachty dzierżących duże kró- 
lewszczyzny. Był to majątek Stanisława Poniatowskiego, podskarbiego wielkiego litewskiego, którego potęga majątkowa wynikała głównie z dzierżenia starostw bohusławskiego, korsuńskiego, kaniowskiego i sienickiego, składajacych się z 3 miast i 108 wsi oraz dużo mniejszych dóbr dziedzicznych (klucze trachtamirowski - 8 i tahaniecki - 10). Dobra te, zarówno dziedziczne, jak i starostwa, leżały we wschodniej i południowo-wschodniej części pow. kijowskiego. Dzięki posiadanym królewszczyznom do rangi czwartego majątku w województwie urastały dobra Antoniego Jabłonowskiego, kasztelana krakowskiego, który posiadał starostwo czehryńskie (3 miasta i 35 wsi) oraz dziedziczny klucz medwedowski (część miasta, 17 wsi i 2 części). Dobra dziedziczne i starostwa dzierżone przez Jabłonowskiego, podobnie jak w wypadku Poniatowskiego, leżały w południowo-wschodniej części pow. kijowskiego. Mniejszymi dobrami dysponował Kajetan Iliński, starosta żytomierski, który obok 12 wsi dziedzicznych posiadał również starostwo żytomierskie, złożone $\mathrm{z}$ miasta i 10 wsi.

Magnackimi z racji swej wielkości były również dobra metropolii kijowskiej (miasto i 67 wsi), dobra stołowe biskupów kijowskich, będące uposażeniem biskupa kijowskiego Kacpra Kazimierza Cieciszowskiego (miasto i 22 wsie). W sumie 16 wielkich majątków ziemskich obejmowało 835 całych i części miejscowości, co stanowiło około $46 \%$ osad woj. kijowskiego.

Druga grupa majątkowa była szlachta posiadająca od 11 do 20 wsi. W 1789 r. na terenie woj. kijowskiego istniało 18 majątków spełniających te kryteria. Do 18 posiadaczy ziemskich, którzy stanowili $6,8 \%$ właścicieli, należało 24 całych i 2 części miast oraz 237 wsi i 18 części, co daje $18,1 \%$ własności szlacheckiej. Do szlachty bogatej należało $25,1 \%$ osad w pow. kijowskim i $15,7 \% \mathrm{w}$ żytomierskim. Znacznie słabiej była ona reprezentowana w pow. owruckim (8,3\%), zdominowanym przez wielka i drobną własność. Tej wielkości majątki posiadali Jan Hański, chorąży kijowski (miasto i 17 wsi); Kacper Lubomirski (miasto i 18 wsi); wymieniani już Antoni Jabłonowski, kasztelan krakowski (część miasta, 17 wsi i 2 części), posiadający również starostwo czehryńskie, i Stanisław Poniatowski, podskarbi wielki litewski (miasto i 17 wsi), który miał również starostwa bohusławskie, korsuńskie, kaniowskie i sienickie; bracia Józef i Filip Olizarowie (miasto, 15 wsi i 2 części); bracia Jan Nepomucen i Krzysztof Karwiccy (17 wsi); Adam i Seweryn Rzewuscy (miasto i 15 wsi); Andrzej Dubrawski, sędzia grodzki żytomierski (miasto i 15 wsi), Wincenty hrabia Tyszkiewicz, referendarz litewski (miasto i 14 wsi); Józef Bierzyński, podkomorzy żytomierski (14 wsi i 5 części); Stefan Lubowidzki, generał-major wojsk koronnych 
(2 miasta, jurydyka, 12 wsi i 2 części); Józef Młodecki (miasto i 13 wsi); Stanisław Pruszyński, kasztelan żytomierski (10 wsi i 7 części); Kajetan Iliński, starosta żytomierski (12 wsi); kniaziowie Szujscy (miasto i 11 wsi); Michał Głębocki, wojski większy owrucki (miasto i 11 wsi); Tadeusz Niemirycz, podkomorzy owrucki (miasto i 10 wsi) i August Dobrogost Jabłonowski, wojewodzic nowogrodzki (miasto i 10 wsi).

Grupa szlachty zamożnej, posiadającej 6-10 całych wsi i miast, liczyła 29 właścicieli ziemskich. W ich rękach znajdowało się 18 miast i 2 części miast oraz 185 wsi i 9 części wsi, co stanowiło 13,8\% osad województwa - najwięcej w pow. żytomierskim, w którym co czwarta wieś i miasto należały do zamożnej szlachty (zob. tab. 2). Było wśród nich po czterech właścicieli majątków złożonych z 10 i 9 wsi i miast, pięciu szlachciców posiadało 8 i 7 wsi i miast oraz jedenastu posiadających 6 wsi i miast. Ta grupa własności ziemskiej niemal nie występowała w pow. owruckim, w którym należało do niej zaledwie 5,8\% osad.

Znacznie liczniej była reprezentowana szlachta średnia, do której zaliczyłem posiadaczy od 1 do 5 całych wsi lub miast. Grupa ta liczyła 142 właścicieli (53\%), którzy posiadali 12 całych i 3 części miast oraz 301 wsie i 43 części wsi, w sumie $22,9 \%$ osad województwa. Własność średnioszlachecka była $\mathrm{w}$ miarę równomiernie reprezentowana w każdym $\mathrm{z}$ trzech powiatów, posiadając $\mathrm{w}$ nich od $20,9 \%$ wsi i miast w pow. kijowskim do $25,9 \% \mathrm{w}$ żytomierskim. W grupie tej było 10 majątków pięciowioskowych, w tym $5 \mathrm{z}$ miastem, 12 czterowioskowych, w tym $5 \mathrm{z}$ miastem, 18 trzywioskowych, w tym $2 \mathrm{z}$ miastem i jeden dodatkowo z 12 czastkami, 47 dwuwioskowych, w tym 4 z miastem lub częścia miasta oraz 55 jednowioskowych.

Szlachta drobna, posiadająca części wsi, jest najtrudniejsza do określenia, zarówno pod względem liczby właścicieli cząstek, jak i liczby cząstek w poszczególnych wsiach. Jak już zaznaczyłem, przy części wsi posiadanych przez drobną szlachtę komisarze nie wyliczali szczegółowej listy właścicieli, ograniczając się do określenia takich wsi jako posiadanych w częściach, przez co dane odnoszące się do szlachty cząstkowej moga zostać uznane jedynie za wartości przybliżone. $\mathrm{Z}$ imienia i nazwiska lub tylko z nazwiska odnotowano 66 posiadaczy cząstek, którzy stanowili 24,1\% właścicieli. Do drobnej własności należało 72 całych wsi i 32 cząstki wsi i miast, co stanowiło do $6,7 \%$ miejscowości województwa. Własność cząstkowa najliczniej występowała na północy woj. kijowskiego, głównie w pow. owruckim, w którym leżało 57,7\% całych osad i cząstek drobnoszlacheckich, i w północnej części pow. żytomierskiego (31,7\%). W pow. kijowskim było to zaledwie 8 wsi i 3 czastki $(10,6 \%)$. W skali powiatów wsie i miasta należące do drobnej własno- 
ści stanowiły 15,9\% osad pow. owruckiego, 6,5\% żytomierskiego i 1,6\% kijowskiego (zob. tab. 2).

Tabela 2. Wielkość własności szlacheckiej w powiatach woj. kijowskiego w $1789 \mathrm{r}^{35}$

\begin{tabular}{|c|c|c|c|c|c|c|c|c|c|c|c|c|c|c|c|c|}
\hline \multirow{4}{*}{$\begin{array}{c}\text { Katego- } \\
\text { ria } \\
\text { włas- } \\
\text { ności }\end{array}$} & \multicolumn{16}{|c|}{ Powiat } \\
\hline & \multicolumn{4}{|c|}{ kijowski } & \multicolumn{4}{|c|}{ owrucki } & \multicolumn{4}{|c|}{ żytomierski } & \multicolumn{4}{|c|}{ razem } \\
\hline & \multicolumn{3}{|c|}{$\begin{array}{c}\text { miasta } \\
\text { i wsie }\end{array}$} & \multirow[b]{2}{*}{$\%$} & \multicolumn{3}{|c|}{$\begin{array}{c}\text { miasta } \\
\text { i wsie }\end{array}$} & \multirow[b]{2}{*}{$\%$} & \multicolumn{3}{|c|}{$\begin{array}{c}\text { miasta } \\
\text { i wsie }\end{array}$} & \multirow[b]{2}{*}{$\%$} & \multicolumn{3}{|c|}{ miasta i wsie } & \multirow[b]{2}{*}{$\%$} \\
\hline & సँ & 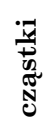 & 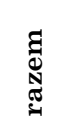 & & ฮँ & 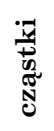 & 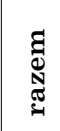 & & हँ & 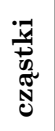 & 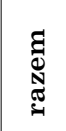 & & ฮँ & 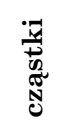 & 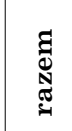 & \\
\hline $\begin{array}{l}\text { szlachta: } \\
\text { - drobna }\end{array}$ & 8 & 3 & 11 & 1,6 & 41 & 19 & 60 & 15,9 & 23 & 10 & 33 & 6,5 & 72 & 32 & 104 & 6,7 \\
\hline - średnia & 141 & 2 & 143 & 20,9 & 49 & 37 & 86 & 22,8 & 124 & 7 & 131 & 25,9 & 314 & 46 & 360 & 22,9 \\
\hline - zamożna & 81 & 4 & 85 & 12,5 & 18 & 4 & 22 & 5,8 & 105 & 3 & 108 & 21,4 & 204 & 11 & 215 & 13,8 \\
\hline - bogata & 163 & 6 & 169 & 25,1 & 23 & 11 & 34 & 9,0 & 75 & 3 & 78 & 15,4 & 261 & 20 & 281 & 18,1 \\
\hline$-\underset{\text { teria }}{\text { magna- }}$ & 249 & - & 249 & 36,8 & 164 & 11 & 175 & 46,5 & 105 & - & 105 & 20,9 & 518 & 11 & 529 & 33,9 \\
\hline $\begin{array}{l}\text { nieznany } \\
\text { właściciel }\end{array}$ & 21 & - & 21 & 3,1 & - & - & - & - & 50 & - & 50 & 9,9 & 70 & 1 & 71 & 4,6 \\
\hline razem & 663 & 15 & 678 & 100 & 295 & 82 & 377 & 100 & 482 & 23 & 505 & 100 & 1440 & 120 & 1560 & 100 \\
\hline
\end{tabular}

Komisarze, sporządzając protokół „Ofiary 10 i 20 grosza”, obok nazwy wsi lub miasta zaznaczali również, jakim prawem do majątku dysponował jego posiadacz. Na podstawie tych zapisów można wyróżnić dwie zasadnicze grupy majątków: posiadanych prawem dziedzicznym i prawem czasowym. Do drugiej grupy należy zaliczyć wsie i miasta posiadane prawem dożywotnim, zastawnym lub dzierżawnym - w wypadku woj. kijowskiego wyłącznie dobra szlacheckie. Na terenie Kijowszczyzny użytkowano w ten sposób 258 wsi, miast i cząstek ${ }^{36}$, co stanowiło 16,5\% własności szlacheckiej i dotyczyło 14,3\% majątków (38).

W grupie 190 miejscowości, przy których podano informację o właścicielu, najliczniej reprezentowana była szlachta najzamożniejsza. Ponad połowa czasowo wyłączonych z majątku miejscowości należała do magnaterii lub bogatej szlachty (144 miejscowości), przy czym aż 111 z nich należało do magnaterii (43\%). Pozostałe wsie były własnością głównie szlachty zamożnej i średniej, choć spora grupę stanowiły miejscowości

${ }^{35}$ Bibl. ZNiO, rkps 500/III, Protokół ofiary 10 i 20 grosza województwa kijowskiego, s. $1-90$.

${ }^{36} 8$ miast i 2 części, 239 całych i 9 części wsi. 
należące do nieznanych z imienia i nazwiska właścicieli. Podobnie - od najbogatszej do najbiedniejszej szlachty - rozkładały się proporcje, jeśli idzie o udział miejscowości oddawanych w „obce ręce” w całym mająt$\mathrm{ku}$, jak i o liczbę właścicieli decydujących się na czasowe odstapienie części majątku (zob. tab. 3 i 4).

Tabela 3. Miasta i wsie oddane w dzierżawę w zależności od kategorii własności w woj. kijowskim w 1789 r. $^{37}$

\begin{tabular}{l|c|c|c|c}
\hline \multirow{2}{*}{$\begin{array}{l}\text { Kategoria } \\
\text { własności }\end{array}$} & $\begin{array}{c}\text { Ogół po- } \\
\text { siadanych } \\
\text { miast, wsi } \\
\text { i cząstek }\end{array}$ & \multicolumn{2}{|c|}{$\begin{array}{c}\text { Liczba wydzierżawionych } \\
\text { miast i wsi }\end{array}$} & $\begin{array}{c}\text { Odsetek miast } \\
\text { Od wsi oddanych } \\
\text { i posesjé w skali } \\
\text { poszczególnych ka- } \\
\text { tegorii własności }\end{array}$ \\
\cline { 3 - 5 } & $\begin{array}{c}\text { Liczba bez- } \\
\text { względna }\end{array}$ & $\%$ & 1,9 \\
szlachta: & 104 & 2 & 0,8 & 5,8 \\
- drobna & 360 & 21 & 8,1 & 10,7 \\
- średnia & 215 & 23 & 8,9 & 11,7 \\
- zamożna & 281 & 33 & 12,8 & 21,0 \\
- bogata & 529 & 111 & 43,0 & 95,8 \\
- magnateria & 71 & 68 & 26,4 & - \\
nieznany właściciel & 1560 & 258 & 100 & \\
razem & \multicolumn{2}{|}{}
\end{tabular}

Tabela 4. Struktura majątkowa szlachty oddającej dobra w czasowa posesję w woj. kijowskim w 1789 r. $^{38}$

\begin{tabular}{|c|c|c|c|c|}
\hline \multirow{2}{*}{$\begin{array}{l}\text { Kategoria } \\
\text { własności }\end{array}$} & \multirow{2}{*}{$\begin{array}{l}\text { Ogół } \\
\text { właścicieli }\end{array}$} & \multicolumn{2}{|c|}{$\begin{array}{l}\text { Liczba właścicieli wydzier- } \\
\text { żawiających wsie i miasta }\end{array}$} & \multirow{2}{*}{$\begin{array}{c}\text { Odsetek właści- } \\
\text { cieli oddających } \\
\text { w posesję wsie } \\
\text { i miasta w skali } \\
\text { poszczególnych } \\
\text { kategorii } \\
\text { własności }\end{array}$} \\
\hline & & $\begin{array}{c}\text { Liczba } \\
\text { bezwzględna }\end{array}$ & $\%$ & \\
\hline $\begin{array}{l}\text { szlachta: } \\
\text { - drobna }\end{array}$ & 66 & 1 & 5,3 & 1,5 \\
\hline - średnia & 142 & 13 & 34,2 & 9,2 \\
\hline - zamożna & 29 & 10 & 26,3 & 33,3 \\
\hline - bogata & 18 & 7 & 18,4 & 38,9 \\
\hline - magnateria & 11 & 6 & 15,8 & 54,5 \\
\hline razem & 266 & 37 & 100 & - \\
\hline
\end{tabular}

${ }^{37}$ Bibl. ZNiO, rkps 500/III, Protokół ofiary 10 i 20 grosza województwa kijowskiego, s. $1-90$.

${ }^{38}$ Tamże. 
Warto zaznaczyć, że pomimo tego, iż puszczanie wsi w dzierżawę, zastaw lub oddawanie $\mathrm{w}$ dożywocie praktykowano $\mathrm{w}$ co drugim majątku magnackim, to większość wsi oddanych w „obce ręce” należała do dwóch majątków. W dzierżawie znajdował się cały, 21-wioskowy majątek feldmarszałka Potiomkina oraz składający się z miasta, 68 wsi i cząstki majątek Rokickich, który niemal w całości został oddany w „obce ręce” (miasto i 15 wsi w zastawie, przy 51 wsiach nie określono formy użytkowania) - w sumie 88 miejscowości.

Zasadnicza różnica, jeśli chodzi o formułę prawna czasowego oddawania części posiadanych miejscowości w „obce ręce” zachodzi między magnateria a pozostałymi kategoriami własności. Własność magnacka najczęściej była dzierżawiona $(40,4 \%)$ i oddawana w zastaw $(40,4 \%)$, rzadziej w dożywocie (19,2\%). Przewaga dzierżaw i zastawów mogła wynikać z zapotrzebowania na gotówkę lub z trudności w zarządzaniu osobistym bądź przez ekonoma często rozproszonym i leżącym w kilku województwach majątkiem, przez co decydowano się na wydzierżawienie jego części, z czym zapewne mamy do czynienia w wypadku majątku feldmarszałka Potiomkina. W pozostałych typach własności dużo większe znaczenie miały dożywocia. W oddanych w „obce ręce” majątkach bogatej szlachty dożywocia stanowiły $84,6 \%$ miejscowości, a dzierżawy i zastawy odpowiednio 10,3 i $5,1 \%$ osad. W przypadku szlachty zamożnej miejscowości czasowo odstapione w niemal w równym stopniu były zastawami (55\%), jak i dożywociami (45\%), a szlachty średniej - zastawami było 50\%, dożywociami $35,7 \%$, a dzierżawami $24,3 \%$ odstapionych osad.

Największym zespołem oddanym w „obce ręce” było miasto i 50 wsi należących do Rokickich, trzymanych nieznanym prawem przez Straszewiczów, marszałkowiców upickich. Pozostałe dobra Rokickich, również nieznanym prawem, posiadali nieokreśleni imionami Oskirkowie (7), Pawsza (5) i Aleksandrowicz (4). Drugim pod względem wielkości był zespół majątkowy złożony z 2 miast i 17 wsi będących w dożywociu Zofii Józefy z Lubomirskich Ponińskiej, żony Adama, podskarbiego wielkiego koronnego. Ten majątek, jako jedyny w województwie, został w całości odstapiony osobom trzecim. Trzecim pod względem wielkości majątkiem był zespół 16 wsi nieznanego właściciela, trzymanych nieokreślonym prawem przez Jerzego Sylwestrowicza, łowczego wileńskiego. Jako większe należy jeszcze wymienić dożywocie Marii z Lubomirskich Radziwiłłowej, żony Karola Stanisława, miecznika litewskiego (miasto i 7 wsi), dożywocie Anny z Niemierzyców Pawszowej, wdowy po Janie podkomorzym owruckim (2 miasta i 5 wsi), dożywocie Kordyszowej (miasto i 5 wsi) oraz zespół majątkowy trzymany prawem 
zastawnym i dożywotnim przez Czajkowskiego (miasto i 4 wsie), będący własnością wspomnianej wyżej Ponińskiej. Wśród pozostałych zespołów majątkowych u czasowych użytkowników znalazły się 2 zespoły złożone z 4 miejscowości, 7 zespołów złożonych z 3 miejscowości, 15 złożonych z 2 miejscowości i 90 złożonych z miasta lub wsi.

\section{Struktura dochodów z dóbr ziemskich w województwie kijowskim}

W świetle protokołu „Ofiary 10 i 20 grosza” oraz lustracji królewszczyzn dobra ziemskie w woj. kijowskim dawały roczny dochód w wysokości 6598091 zł, z czego ze starostw uzyskano 1094433 zł, z dóbr dziedzicznych 5132201 zł, a z dóbr kościelnych 371457 zł (zob. tab. 5) ${ }^{39}$. Rozkład struktury dochodów trzech typów własności w połaczeniu z udziałem $\mathrm{w}$ strukturze własności wyglądał następująco: dochody z dóbr szlacheckich stanowiły $78 \%$ ogólnej kwoty i obejmowały $77,8 \%$ wsi i miast, w wypadku dóbr kościelnych było to odpowiednio 5,6 i 8,4\%, a dóbr królewskich: 16,6 i 12,7\%. Brak korelacji między struktura własności a struktura dochodów w przypadku dóbr kościelnych i królewszczyzn wynika z ich geograficznego położenia i stanu zagospodarowania. Mógł również wynikać z różnic w szacowaniu dochodów zarówno z dóbr królewskich, jak i kościelnych oraz szlacheckich.

Tabela 5. Struktura dochodów w zależności od typu własności ziemskiej w woj. kijowskim w 1789 r. $^{40}$

\begin{tabular}{|c|c|c|c|c|c|c|c|c|}
\hline \multirow{3}{*}{ Powiat } & \multicolumn{8}{|c|}{ Typ własności ziemskiej } \\
\hline & \multicolumn{2}{|c|}{ szlachecka } & \multicolumn{2}{|c|}{ duchowna } & \multicolumn{2}{|c|}{ królewska } & \multicolumn{2}{|c|}{ razem } \\
\hline & $\begin{array}{c}\text { Licz- } \\
\text { ba bez- } \\
\text { względna }\end{array}$ & $\%$ & $\begin{array}{c}\text { Licz- } \\
\text { ba bez- } \\
\text { względna }\end{array}$ & $\%$ & $\begin{array}{c}\text { Licz- } \\
\text { ba bez- } \\
\text { względna }\end{array}$ & $\%$ & $\begin{array}{c}\text { Licz- } \\
\text { ba bez- } \\
\text { względna }\end{array}$ & $\%$ \\
\hline kijowski & 3118611 & 72,0 & 173008 & 4,0 & 1042293 & 24,0 & 4333912 & 65,7 \\
\hline owrucki & 521530 & 84,7 & 84669 & 13,7 & 9995 & 1,6 & 616194 & 9,3 \\
\hline żytomierski & 1492060 & 90,5 & 113780 & 6,9 & 42145 & 2,6 & 1647985 & 25,0 \\
\hline razem & 5132201 & 77,8 & 371457 & 5,6 & 1094433 & 16,6 & 6598091 & 100 \\
\hline
\end{tabular}

${ }^{39}$ Sa to sumy skorygowane o liczne pominięcia i omyłki komisarzy. Podsumowali oni dochód z dóbr szlacheckich i duchownych jedynie na 5081171 zł, 25 gr oraz 2 i pół szelaga.

${ }^{40} \mathrm{Bibl}$. ZNiO, rkps 500/III, Protokół ofiary 10 i 20 grosza województwa kijowskiego, s. 1-90; AGAD, ASK, oddział XLVI, sygn. 4, Lustracja królewszczyzn województwa kijowskiego, 1789; AJZR, cz. 7, t. 3, s. 199-596. 
Lustrowanie królewszczyzn wiązało się z obecnością lustratorów w poszczególnych starostwach i dzierżawach, i sporządzaniem inwentarzy na gruncie, a przez to lepszym oszacowaniem stanu dóbr i płynących z nich dochodów. $Z$ treści dokumentu nie wynika, czy lustrację przeprowadzono na gruncie, czy też ograniczono się tylko do wglądu $\mathrm{w}$ istniejace już inwentarze. Za druga możliwościa przemawia działalność Sejmu Wielkiego, który wyznaczał krótkie terminy realizacji spraw podatkowych, a także treść lustracji. W swojej konstytucji sejm nakazał lustratorom rozpocząć pracę 17 lipca, a zakończyć w terminie wyznaczonym dla lustracji dóbr ziemiańskich, czyli do końca września ${ }^{41}$. Do tego dochody zapisane w lustracji były wartością średnią $\mathrm{z}$ trzech poprzednich lat, spisana z inwentarzy, a nie sumą uzyskana w 1789 r. Natomiast przeprowadzenie Ofiary wieczystej [...] na powiększenie sił krajowych - z założenia polegało jedynie na zaprzysiężeniu prawdziwości danych zapisanych w inwentarzach przedłożonych komisjom powiatowym przez dziedziców lub dzierżawców. Komisje tylko wyjątkowo miały bezpośrednio lustrować dobra duchowne i szlacheckie. Brak realnej kontroli „oświadczeń o dochodach” musiał prowadzić do zaniżania dochodów. Ponadto na wymiar dochodu i podatku wpływały niskie taksy przyjmowane przez lokalne komisje, na co zwracał uwage Roman Rybarski. Stwierdził on dowolność obliczania intraty przez komisarzy różnych województw. Wedle ustawy sejmowej mieli układać taksę pańszczyzny, robocizny, zboża i innych rzeczy przynoszących intratę „stosownie do zwyczaju województwa, ziemi lub powia$\mathrm{tu}{ }^{42}$. Było to o tyle uzasadnione, że „powiaty to były wielkie jednostki administracyjne, o różnej urodzajności ziemi, o różnym położeniu gospodarstw. W innym położeniu jest majątek, który leży nad spławna rzeka, a w innym folwark leżący odległy od tej rzeki o kilka mil drogi lub bezdroża. Ustanawiając jedną taksę dla całego powiatu, ułatwiano zadanie komisarzom, ale siłą rzeczy przyjmowano dla całego powiatu najniższy szacunek, by nikogo nie skrzywdzič"43.

Pomimo zaznaczonych powyżej prawdopodobnych różnic w szacowaniu dóbr królewskich oraz duchownych i dziedzicznych sam proces wyliczenia dochodów nie tłumaczy braku korelacji między struktura własności i strukturą dochodów w przypadku dóbr kościelnych i królewszczyzn. Wydatny w tym udział miało przede wszystkim położenie geograficzne i poziom zagospodarowania dóbr. Szacunkowy przeciętny dochód z jednostki osadniczej w woj. kijowskim w 1789 r. wynosił

\footnotetext{
${ }^{41}$ VL, s. 95, 100.

${ }^{42}$ R. Rybarski, dz. cyt., s. 323.

${ }^{43}$ Tamże.
} 
3760 zł (bez miast 3139 zł) ${ }^{44}$ i znacznie różnił się w odniesieniu do poszczególnych powiatów. Największe dochody osiagali właściciele dóbr w pow. kijowskim (4821 zł, bez miast $4090 \mathrm{zł}$ ), następnie w pow. żytomierskim i owruckim (odpowiednio: 2810, bez miast $2268 \mathrm{zł;} 1774 \mathrm{zł}$, bez miast 1482 zl). Na podstawie sumariusza nie sposób rozstrzygać o przyczynach tak znacznych różnic $\mathrm{w}$ dochodach $\mathrm{w}$ poszczególnych powiatach. Niewątpliwie mamy tu do czynienia z różnicami w poziomie gospodarczo-osadniczym, na co wskazuje znaczny odsetek futorów i słobód w pow. owruckim, mogących świadczyć o pustkach osadniczych i próbach ich zagospodarowania (zob. tab. 6). Dobra kościelne

Tabela 6. Przeciętny dochód z miast i wsi w województwie kijowskim w 1789 r. ${ }^{45}$

\begin{tabular}{|c|c|c|c|c|}
\hline Powiat & Typ osady & Liczba osad & $\begin{array}{l}\text { Średni do- } \\
\text { chód }\end{array}$ & $\begin{array}{l}\text { Odsetek } \\
\text { futorów } \\
\text { i słobód }\end{array}$ \\
\hline \multirow{5}{*}{ kijowski } & miasta & 60 & 14951 & \multirow{5}{*}{5,9} \\
\hline & wsie & 782 & 4250 & \\
\hline & futory i słobody & 49 & 1526 & \\
\hline & wsie, futory, słobody & 831 & 4090 & \\
\hline & razem & 891 & 4821 & \\
\hline \multirow{5}{*}{ owrucki } & miasta & 7 & 12820 & \multirow{5}{*}{16,7} \\
\hline & wsie & 221 & 1700 & \\
\hline & futory i słobody & 44 & 387 & \\
\hline & wsie, futory, słobody & 265 & 1482 & \\
\hline & razem & 272 & 1774 & \\
\hline \multirow{5}{*}{ żytomierski } & miasta & 23 & 12300 & \multirow{5}{*}{4,0} \\
\hline & wsie & 387 & 2300 & \\
\hline & futory i słobody & 16 & 1497 & \\
\hline & wsie, futory, słobody & 403 & 2268 & \\
\hline & razem & 426 & 2810 & \\
\hline \multirow{5}{*}{ razem } & miasta & 90 & 14108 & \multirow{5}{*}{7,3} \\
\hline & wsie & 1390 & 3302 & \\
\hline & futory i słobody & 109 & 1062 & \\
\hline & wsie, futory, słobody & 1499 & 3139 & \\
\hline & razem & 1589 & 3760 & \\
\hline
\end{tabular}

${ }^{44}$ Podstawą do obliczenia przeciętnego dochodu było 1589 wsi i miast. Pominięto osady, w przypadku których dochód spisano łącznie dla kilku punktów osadniczych.

${ }^{45}$ Bibl. ZNiO, rkps 500/III, Protokół ofiary 10 i 20 grosza województwa kijowskiego, s. 1-90; AGAD, ASK, oddział XLVI, sygn. 4, Lustracja królewszczyzn województwa kijowskiego, 1789; AJZR, cz. 7, t. 3, s. 199-596. 
były w miarę równomiernie rozłożone we wszystkich trzech powiatach, podczas gdy około 90\% królewszczyzn leżało w najlepiej zagospodarowanym pow. kijowskim. Poza tym porównanie wsi królewskich z duchownymi leżącymi w pow. kijowskim prowadzi do wniosku, że lepiej zagospodarowanymi były te pierwsze. W dobrach królewskich z osady miejskiej i wiejskiej uzyskiwano średnio $4828 \mathrm{zl}$ (bez miast $4110 \mathrm{zl}$ ), a w dobrach kościelnych zaledwie 2755 zł (bez miast 2414 zł). Za tym, że różnica między wielkością własności duchownej a jej dochodowością w porównaniu z królewszczyznami wynikała z ich słabszego zagospodarowania i rozmieszczenia geograficznego, a nie $\mathrm{z}$ różnic $\mathrm{w}$ sposobie przeprowadzenia szacunku dochodów przemawiają również dane dotyczące dóbr szlacheckich. Były one szacowane wedle tych samych zasad co duchowne, a średni dochód $\mathrm{z}$ osady $\mathrm{w}$ pow. kijowskim wynosił 4952 zł (bez miast $4255 \mathrm{zł}$ ).

Dochody z dóbr królewskich. Jak zaznaczyłem wcześniej, dochody płynące z królewszczyzn wynosiły prawie 1 mln 100 tys. zł i pochodziły głównie ze starostw leżących w pow. kijowskim (zob. tab. 5).

Najbardziej dochodowymi starostwami były bohusławskie i kaniowskie, będące w posiadaniu Stanisława Poniatowskiego, podskarbiego wielkiego Wielkiego Księstwa Litewskiego, starostwo czerkaskie Hieronima Sanguszki, wojewody wołyńskiego, i czehryńskie Antoniego Jabłonowskiego, kasztelana krakowskiego (zob. tab. 7).

Tabela 7. Dochody starostw i ich dzierżawcy w woj. kijowskim w latach 1786-178846

\begin{tabular}{l|c|l|l}
\hline \multicolumn{1}{c|}{ Starostwo } & $\begin{array}{c}\text { Dochód } \\
\text { starostwa }\end{array}$ & \multicolumn{1}{|c|}{ Dzierżawca } & \multicolumn{1}{c}{ Powiat } \\
bohusławskie & 233564 & $\begin{array}{l}\text { Poniatowski Stanisław, podskarbi wielki } \\
\text { Wielkiego Księstwa Litewskiego }\end{array}$ & kijowski \\
kaniowskie & 176919 & jw. & kijowski \\
czerkaskie & 132528 & Sanguszko Hieronim, wojewoda wołyński & kijowski \\
czehryńskie & 132223 & Jabłonowski Antoni, kasztelan krakowski & kijowski \\
korsuńskie & 114249 & $\begin{array}{l}\text { Poniatowski Stanisław, podskarbi wielki } \\
\text { Wielkiego Księstwa Litewskiego }\end{array}$ & kijowski \\
taraszczańskie & 55085 & Piastowski Mikołaj \\
romanowskie & 49104 & Lubomirski Józef \\
żytomierskie (grodowe) & 39351 & Iliński Kajetan & kijowski \\
kahorlickie & 35954 & Tarnowski Jan & żytomierski \\
hermanowskie & 27403 & Dąrowski Kasper & kijowski \\
kijowski
\end{tabular}

${ }^{46}$ AGAD, ASK, oddział XLVI, sygn. 4, Lustracja królewszczyzn województwa kijowskiego, 1789; AJZR, cz. 7, t. 3, s. 199-596. 


\begin{tabular}{l|r|l|l} 
szawulińskie & 24670 & $\begin{array}{l}\text { Bierzyńska Ludwika z Ponińskich, kasz- } \\
\text { telanowa żytomierska }\end{array}$ & kijowski \\
rożowskie & 17847 & Cetner Ignacy, wojewoda bełski & kijowski \\
dymirskie & 16815 & Potocki Kajetan & kijowski \\
owruckie (grodowe) & 7422 & Stecki Jan, starosta owrucki & owrucki \\
taborowskie & 6424 & Cyryna Katarzyna z Rostkowskich & kijowski \\
siennickie & 4050 & Poniatowski Stanisław, podskarbi wielki & Wielkiego Księstwa Litewskiego \\
Szołomek i Słoboda & 2573 & Komar Andrzej & owrucki \\
niechworowskie & 15458 & Kaniewski Ignacy, stolnik różański & kijowski \\
Zwinogrodka ${ }^{47}$ & $\cdots$ & Sołtykowa Salomea z Brzozowskich & kijowski \\
Weresy & 2794 & Stecki Jan, starosta owrucki & żytomierski \\
\hline
\end{tabular}

Dochody z dóbr duchownych. W świetle sumariusza „Ofiary 10 i 20 grosza" dochody duchowieństwa kijowskiego wynosiły nieco ponad 370 tys. zł, co stanowiło zaledwie 5,6\% dochodów z dóbr ziemskich województwa. W skali powiatów większy udział w strukturze dochodów miały dochody duchowieństwa w pow. owruckim, ale nominalnie była to suma niższa od sum uzyskiwanych w pozostałych powiatach (zob. tab. 5).

W przypadku duchowieństwa opodatkowane zostały nie tylko dochody uzyskiwane z ziemi, ale również dziesięciny i meszne płacone na rzecz Kościoła oraz sumy czynszowe i zapisy wieczyste na jego rzecz, zabezpieczone na dobrach, które zostały wyłączone z intrat dóbr dziedzicznych, a potrącone z dochodów duchownych.

Jak już wspomniano, od podatku zwolniono fundusze na seminaria diecezjalne, fundusze wikariuszy i misjonarzy „, pięćset złotych tylko na osobę dochodu mające"; szpitale dla podrzutków, chorych i ubogich przeznaczające cały dochód na ich utrzymanie; fundusze i konwikty ubogich studentów oraz plebanów obu obrządków bez dziesięciny, jakichkolwiek sum i poddanych. Niższy, ziemiański podatek mieli opłacać plebani mający curam animarum, którzy nie mieli pewnej i stałej intraty ponad 2 tys. zł; klasztory, które miały tylko 2 tys. zł dochodu na całe zgromadzenie; konwenty, które utrzymywały swoim kosztem szkoły publiczne mające co najmniej 3 profesorów, aprobowane przez Komisję Edukacji oraz zgromadzenia zakonne, które zostały powołane

${ }^{47}$ Starostwo zwinogrodzkie, jak i większość linii granicznej, było terytorium spornym między woj. kijowskim i bracławskim. Lustratorowie woj. kijowskiego spisali tylko miasto Zwinogrodkę bez kwoty podatku, zaznaczając, że starostwo zostało spisane z województwem bracławskim; AJZR, cz. 7, t. 3, s. 533-535. 
w celu edukacji publicznej. Na pomniejszenie podatku o sumy wyłożone na prowadzenie szkoły mogły liczyć klasztory, które w porozumieniu z Komisją Edukacji podejmą się utrzymywania szkół publicznych ${ }^{48}$.

Sumy uzyskiwane przed rzymsko- i greckokatolickie parafie, klasztory, szkoły itp. były zazwyczaj niewielkie. Z dóbr duchownych najwyższe dochody przynosiły dobra należace do greckokatolickiej metropolii kijowskiej, która uzyskiwała 156 tys. zł rocznie. 71 tys. zł przynosiły dobra stanowiące uposażenie Kaspra Kazimierza Kolumny Cieciszowskiego, biskupa kijowskiego. Większą sumę, ponad 13 tys. zł, przynosiły jeszcze tylko dobra należące do nieznanego opactwa owruckiego, dominikańskiego lub bazyliańskiego. Nieco ponad 8 tys. zł dochodu z dóbr ziemskich miały klasztory karmelitów berdyczowskich i bazylianek koreckich, a majątek rzymskokatolickiej kapituły kijowskiej - 7,5 tys. zł. Pozostałe 18 duchownych majątków ziemskich dawało poniżej 5 tys. zł rocznego dochodu.

W sumie majątki należące do duchowieństwa przynosiły $287282 \mathrm{zł}$, różnego rodzaju zapisy i ujęte łącznie sumy uiszczane przez parochów greckokatolickich 84175 zł, a łączny dochód duchowieństwa wynosił 371457 zł.

Dochody z dóbr dziedzicznych. Na potrzeby analizy struktury dochodów z dóbr dziedzicznych zestawiłem dochody szlacheckie od najniższych do przekraczających 100 tys. zł, dzieląc je w grupy co 500 oraz co 5 i 10 tys. zł dochodu (zob. tab. 8). Posługując się danymi zebranymi w tabeli 8 i nawiązując do pięciostopniowej struktury szlachty zaproponowanej przez Dworzaczka, podział szlachty ze względu na dochody zawęziłem do pięciu grup, przyjmując następujące przedziały: powyżej 100 tys. zł, od 50 do 100 tys. zł, od 25 do 50 tys. zł, od 10 do 25 tys. zł oraz poniżej 10 tys. zł (zob. tab. 9). Pewne wątpliwości może budzić ostatnia grupa dochodowa, mieszczaca aż 68\% właścicieli ziemskich o wyraźnie zróżnicowanych dochodach. Zestawiając skrajne wartości, w tej samej grupie mamy szlachcica posiadającego 10 tys. zł dochodu i szlachcica, który mógł wykazać zaledwie 100 zł rocznego dochodu, zwłaszcza że średni dochód z osady wiejskiej wynosił 3139 zł (zob. tab. 6). Z tego też względu grupa ta została szczegółowo rozpisana w tabeli 10 . W tabelach 8-10 nie zostały uwzględnione dochody płynące z 70 miejscowości, przy których nie zaznaczono właściciela. Suma, która uzyskiwano z tych majatków, to prawie 250 tys. zł.

Nieco „zamieszania” wprowadzaja dochody z dzierżawionych starostw przynoszacych spora intratę, nierzadko przekraczająca tę uzy-

${ }^{48}$ VL, s. 73. 
skiwaną z dóbr dziedzicznych. Uwzględniam je, często odnotowując dzierżawców królewszczyzn dwukrotnie: w grupie szlachty, do której przynależą z racji dochodów z dóbr dziedzicznych oraz po zsumowaniu intraty z majątku własnego i królewszczyzny, co wielokrotnie znacznie podnosiło dochód, a co za tym idzie prestiż szlachcica.

Tabela 8. Struktura dochodów z dóbr szlacheckich w woj. kijowskim w 1789 r. (zestawienie rozszerzone $)^{49}$

\begin{tabular}{l|c|c|c|c}
\hline \multirow{2}{*}{$\begin{array}{c}\text { Dochód } \\
\text { w tys. złp }\end{array}$} & \multicolumn{2}{c}{ Liczba majątków } & \multicolumn{2}{c}{ Dochód grupy } \\
\cline { 2 - 4 } & $\begin{array}{c}\text { Liczba bez- } \\
\text { względna }\end{array}$ & $\%$ & $\begin{array}{c}\text { Liczba bez- } \\
\text { względna }\end{array}$ & $\%$ \\
\hline powyżej 100 & 4 & 1,4 & 1382287 & 29,0 \\
$90-100$ & 3 & 1,2 & 281519 & 5,8 \\
$80-90$ & 1 & 0,4 & 80172 & 1,7 \\
$70-80$ & 3 & 1,2 & 224176 & 4,7 \\
$60-70$ & 5 & 1,9 & 328725 & 7,1 \\
$50-60$ & 2 & 0,7 & 101809 & 2,1 \\
$40-50$ & 11 & 4,1 & 493757 & 10,4 \\
$30-40$ & 11 & 4,1 & 372945 & 7,8 \\
$20-30$ & 17 & 6,4 & 429663 & 9,0 \\
$10-20$ & 28 & 10,5 & 413653 & 8,7 \\
$5-10$ & 58 & 21,7 & 416779 & 8,7 \\
$1-5$ & 74 & 27,7 & 218696 & 4,6 \\
$0,5-1$ & 14 & 5,2 & 11357 & 0,2 \\
$0,1-0,5$ & 36 & 13,5 & 7316 & 0,2 \\
razem & 267 & 100 & 4762854 & 100 \\
\hline
\end{tabular}

Dane przedstawione w tabelach 8 i 9 wyraźnie, czego należało się spodziewać, koresponduja ze struktura własności szlacheckiej w województwie. Kumulacji jednej trzeciej wsi i miast w rękach jedenastu osób zaliczonych przeze mnie do magnaterii odpowiadała kumulacja dochodów w rękach kilku osób, choć nie zawsze tych samych. W sumie niemal trzecią część dochodów uzyskiwanych z dóbr ziemskich w woj. kijowskim przynosiły zaledwie cztery majątki (zob. tab. 8 i 9), choć w rzeczywistości generował je głównie majątek Franciszka Ksawerego Branickiego z 1065201 zł rocznego dochodu.

${ }^{49} \mathrm{Bibl}$. ZNiO, rkps 500/III, Protokół ofiary 10 i 20 grosza województwa kijowskiego, s. $1-90$. 
Tabela 9. Struktura dochodów z dóbr szlacheckich w woj. kijowskim w 1789 r. ${ }^{50}$

\begin{tabular}{|c|c|c|c|c|c|}
\hline \multirow{2}{*}{$\begin{array}{c}\text { Dochód } \\
\text { w tys. złp }\end{array}$} & \multicolumn{2}{|c|}{ Liczba właścicieli } & \multicolumn{2}{|c|}{ Dochód grupy } & \multirow{2}{*}{$\begin{array}{l}\text { Średni do- } \\
\text { chód z ma- } \\
\text { jątku w złp }\end{array}$} \\
\hline & $\begin{array}{c}\text { Liczba bez- } \\
\text { względna }\end{array}$ & $\%$ & $\begin{array}{c}\text { Liczba bez- } \\
\text { względna }\end{array}$ & $\%$ & \\
\hline powyżej 100 & 4 & 1,4 & 1382287 & 29,0 & 356569 \\
\hline $50-100$ & 14 & 5,2 & 1016401 & 21,4 & 72600 \\
\hline $25-50$ & 29 & 10,9 & 1065705 & 22,4 & 36748 \\
\hline $10-25$ & 38 & 14,3 & 644313 & 13,5 & 16956 \\
\hline poniżej 10 & 182 & 68,2 & 654148 & 13,7 & 3594 \\
\hline razem & 267 & 100 & 4762854 & 100 & 17838 \\
\hline
\end{tabular}

Możliwość równoczesnej analizy szlacheckich posiadaczy ziemskich pod względem liczby posiadanych wsi i uzyskiwanych z nich dochodów pozwala ustalić liczne przypadki właścicieli, którzy na podstawie liczby posiadanych wsi zostali zaliczeni do poszczególnych kategorii majątkowych, a których dochody płynące z tychże wsi w żadnej mierze nie odpowiadają tej kwalifikacji. Spośród jedenastu szlachciców posiadających ponad 20 wsi i miast dziedzicznych zaledwie dwóch uzyskiwało dochody przekraczajace 100 tys. zł, a aż trzech dochody nieprzekraczające 50 tys. zł.

Tabela 10. Struktura dochodów z dóbr szlacheckich o dochodach poniżej 10 tys. zł w woj. kijowskim w 1789 r. $^{51}$

\begin{tabular}{c|c|c|c|c}
\hline $\begin{array}{c}\text { Przedział do- } \\
\text { chodu (w tysią- } \\
\text { cach zl) }\end{array}$ & \multicolumn{2}{|c|}{ Liczba majątków } & \multicolumn{2}{c}{ Dochód grupy } \\
\cline { 2 - 4 } & $\begin{array}{c}\text { Liczba bez- } \\
\text { względna }\end{array}$ & $\%$ & $\begin{array}{c}\text { Liczba bez- } \\
\text { względna }\end{array}$ & $\%$ \\
\hline $9-10$ & 7 & 3,8 & 66926 & 10,2 \\
$8-9$ & 11 & 6,0 & 93111 & 14,2 \\
$7-8$ & 11 & 6,0 & 82784 & 12,6 \\
$6-7$ & 13 & 7,1 & 84173 & 12,9 \\
$5-6$ & 16 & 8,8 & 89785 & 13,7 \\
$4-5$ & 18 & 9,9 & 78948 & 12,1 \\
$3-4$ & 11 & 6,0 & 39082 & 6,0 \\
$2-3$ & 30 & 16,5 & 77699 & 11,9 \\
$1-2$ & 15 & 8,2 & 22967 & 3,5 \\
$0,5-1$ & 14 & 7,7 & 11357 & 1,8 \\
$0,1-0,5$ & 36 & 19,8 & 7316 & 1,1 \\
razem & 182 & 100 & 654148 & 100 \\
\hline
\end{tabular}

50 Tamże.

51 Tamże. 
$\mathrm{Na}$ strukturę dochodów istotny wpływ miały również profity płynące z dzierżawy królewszczyzn - trzech dzierżawców dóbr królewskich dzięki dzierżonym starostwom osiagało dochody, które nawet po odliczeniu podwójnej kwarty przekraczały 100 tys. zł.

Pod względem wykazanych dochodów potentatem był Franciszek Ksawery Branicki, hetman wielki koronny, uzyskujacy z 4 miast i 182 wsi nieco ponad milion zł rocznego dochodu (1 065201 zł). Drugim pod tym względem, ale z trzykrotnie niższymi dochodami, był Stanisław Poniatowski, podskarbi wielki Wielkiego Księstwa Litewskiego, z 330 tys. zł, którego podstawę finansową stanowiły przede wszystkim cztery starostwa, z nich trzy generowały ponad 100 tys. zł rocznie każde (zob. tab. 7). Dobra dziedziczne Poniatowskiego, klucze trachtamirowski i tahaniecki w pow. kijowskim dawały mu zaledwie 66 tys. zł rocznego dochodu. Trzeci co do wielkości dochód uzyskiwał Antoni Jabłonowski, kasztelan krakowski, który mógł się wykazać 223 tys. zł rocznego dochodu, z czego dobra dziedziczne przynosiły mu nieco ponad 91 tys. zł, a posiadane starostwo czehryńskie 132 tys. zł. Ponad 100 tys. zł z niewielkiego klucza berdyczowskiego uzyskiwał także Mateusz Radziwiłł, dzierżący cztery wsie i miasto, co pod względem liczby posiadanych osad pozwalało zaliczyć go jedynie do średniej szlachty, choć dochód tylko z Berdyczowa przynosił mu rocznie 102 tys. zł, oraz bracia Józef, Wacław i Aleksander Chodkiewiczowie, starościcowie żmudzcy, i Barbara z Lubomirskich Ponińska, trzymająca w dożywociu po pierwszym mężu Kasprze Lubomirskim klucz pawołocki. Zarówno w przypadku Radziwiłła, jak i Chodkiewiczów dochody wynosiły nieco ponad 115 tys. zł, a dochód Ponińskiej to 112 tys. zł.

Majątek tylko tych czterech magnatów (bez posiadaczy starostw), którzy stanowili zaledwie 1,5\% właścicieli ziemskich, przynosił roczny dochód wynoszący $29 \%$ dochodu z dóbr dziedzicznych woj. kijowskiego (zob. tab. 9), a dochód samego Franciszka Ksawerego Branickiego aż $22,4 \%$.

Poza wymienionymi dobrami szlacheckimi dochód przekraczający 100 tys. zł przynosiły jeszcze dobra należące do rzymskokatolickiej metropolii kijowskiej, która z posiadanych wsi i miast uzyskiwała 156 tys. zł rocznie.

Właściciele, którzy ze względu na liczbę posiadanych wsi i miast zostali wcześniej zaliczeni do magnaterii, a nie mogli wykazać się dochodem rocznym przekraczajacym 100 tys. zł, uzyskiwali następujące sumy: Prot Potocki, starościc guzowski - 97 tys. zł, Szczęsny Czacki, były podczaszy wielki koronny - 93 tys. zł, Grigorij Potemkin, feldmarszałek wojsk rosyjskich - 71500 zł, Rokiccy - 69 tys. zł, sukcesorzy 
Jana Pawszy, podkomorzego owruckiego - 66 tys. zł, Kajetan Rościszewski, dziekan katedry kijowskiej - 51250 zł, Jan Stecki, starosta owrucki - 47450 zł, niezidentyfikowany z imienia Prozor - 44200 zł i Jan Nepomucen Iliński, starosta cudnowski - 34860 zł.

Do drugiej grupy majątkowej, o dochodzie z dóbr dziedzicznych między 50 a 100 tys. zł, należało 14 posesjonatów. Poza wymienionymi powyżej osobami, które z racji posiadanych królewszczyzn przekroczyły 100 tys. zł łącznego dochodu z dóbr dziedzicznych i starostw (Stanisław Poniatowski, Antoni Jabłonowski) oraz osobami, które pomimo posiadanych 20 wsi i miast nie osiagnęły z nich dochodów przekraczających 100 tys. zł (Prot Potocki, Szczęsny Czacki, Grigorij Potemkin, Rokiccy, sukcesorzy Jana Pawszy i Kajetan Rościszowski), do tej grupy dochodowej zaliczało się jeszcze 6 posesorów. Byli to bracia Adam i Seweryn Rzewuscy z dochodem nieco ponad 80 tys. zł, Jan Nepomucen i Krzysztof Karwiccy, kasztelanicowie zawichojscy, których roczne dochody wynosiły niemal 79 tys. zł, Józef Młodecki, podkomorzy Jego Królewskiej Mości - z dochodem prawie 74 tys. zł, Stefan Lubowidzki, generał-major wojsk koronnych - 65 tys. zł, Adam Poniński, podskarbi wielki koronny - 63 tys. zł oraz August Dobrogost Jabłonowski, wojewodzic nowogrodzki i rotmistrz kawalerii narodowej - nieco ponad 50 tys. zł. Do grupy tej należałoby zaliczyć również Jana Steckiego, starostę owruckiego, który poza 47 tys. zł dochodu z dóbr dziedzicznych uzyskiwał jeszcze $7500 \mathrm{zł}$ ze starostwa owruckiego, co daje w sumie ponad 54 tys. zł, oraz Kajetana Ilińskiego, starostę żytomierskiego, którego dochód wynosił około 67 tys. zł, z czego 47 tys. z dóbr dziedzicznych i 20 tys. ze starostwa żytomierskiego. Łączny dochód tej grupy majątkowej wynosił nieco ponad milion zł, 21,4\% dochodu z dóbr dziedzicznych (zob. tab. 9). Była to suma o kilkadziesiąt tysięcy zł niższa niż uzyskiwana przez Franciszka Ksawerego Branickiego z dóbr leżących w woj. kijowskim.

Do trzeciej grupy dochodowej, między 25 a 50 tys. zł rocznego dochodu, należało 29 właścicieli ziemskich, którzy łącznie generowali $22,5 \%$ dochodu $\mathrm{z}$ dóbr ziemskich (zob. tab. 9). W grupie tej znalazło się 3 szlachciców, których na podstawie liczby posiadanych osad zaliczono wcześniej do magnaterii oraz 10 zaliczonych do bogatej szlachty. Do magnaterii, poza wymienionym wcześniej Janem Steckim, zaliczeni byli nieznany z imienia Prozor z 44 tys. zł rocznego dochodu z 24 wsi i 2 miast oraz Jan Nepomucen Iliński, starosta cudnowski - 35 tys. zł dochodu z 27 wsi i miasta. Przedstawicielami bogatej szlachty, przynajmniej pod względem posiadanych wsi i miast, w tej grupie dochodowej byli wymieniony wcześniej Kajetan Iliński, a także Józef i Filip Olizarowie i Wincenty Tyszkiewicz, referendarz Wielkiego Księstwa 
Litewskiego - z ponad 47 tys. zł dochodu, Stanisław Pruszyński, kasztelan żytomierski - 40 tys. zł, Józef Bierzyński, podkomorzy żytomierski - 43 tys. zł, Jan Hański, chorąży kijowski - 40 tys. zł, kniaziowie Szujscy - 35 tys. zł, Michał Głębocki, wojski owrucki - 33 tys. zł, Andrzej Dubrawski, sędzia grodzki żytomierski - 29 tys. zł oraz Tadeusz Niemirycz, podkomorzy owrucki - 27 tys. zł dochodu.

Poza wymienionymi 13 dziedzicami do tej grupy dochodowej zaliczono jeszcze 16 innych. Byli to: Antoni Charliński, pułkownik kawalerii narodowej (48 tys. zł), Rafał hr. Tarnowski (47 tys. zł), Franciszek Grocholski, miecznik koronny (40,5 tys. zł), Ambroży Rakowski, starosta stężycki (36 tys. zł), Stanisław Kajetan Giżycki, chorąży kijowski (36 tys. zł), Antoni Pruszyński, stolnik koronny (35 tys. zł), Ignacy i Franciszek Ksawery Działyńscy, wojewodzicowie kaliscy (35 tys. zł), Piotr Hadziewicz, wicebrygadier kawalerii narodowej (34 tys. zł), Seweryn Wisłocki, starosta kopajgrodzki (34 tys. zł), Józefa z Drohojowskich Woroniczowa, kasztelanowa bełska (30 tys. zł), Mikołaj Polanowski, starosta dąbrowieński (30 tys. zł), Adam Bukar, sędzia ziemski żytomierski (30 tys. zł), Ignacy, miecznik chełmski i Wincenty, podczaszy bełski Rulikowscy (29 tys. zł), Józef Sawicki, sędzia graniczny bracławski (28,5 tys. zł), Zachariasz Hański (28,5 tys. zł), Michał Trzeciak, kasztelan owrucki (27 tys. zł).

Czwarta grupa dochodowa składała się 38 dziedziców uzyskujących ze swoich dóbr od 10 do 25 tys. zł rocznie. Dochody tej grupy jako całości to 644 tys. zł, co stanowiło zaledwie 13,5\% dochodu generowanego przez majątki ziemskie w województwie. Wśród 38 posiadaczy ziemskich było 13 szlachciców, którzy ze względu na liczbę posiadanych wsi zostali zaliczeni do szlachty zamożnej $(6-10 \mathrm{wsi})$ i 25 zaliczonych do szlachty średniej (1-5 wsi).

Najliczniejszą grupa była piąta grupa dochodowa, w której skład wchodziło 182 posiadaczy o rocznym dochodzie nieprzekraczającym 10 tys. zł. Uzyskiwali oni łącznie 648 tys. zł, czyli sumę niemal identyczna jak 38 dziedziców z grupy o dochodzie 10-25 tys. zł. Dochodem poniżej 10 tys. mogli się wykazać właściciele nawet kilku wsi. Urbanowscy - posiadający miasteczko i 7 wsi - uzyskiwali z nich zaledwie 6300 zł, Andrzej Komar, starosta szołomski, miał rocznego dochodu 7600 zł z 6 wsi i 2 części wsi, Stanisław Piotr Mianowski oraz Hipolit i Nikifor Proskurowie mieli po około 5400 zł z 6 wsi. Należy przy tym podkreślić, że dochód poniżej 10 tys. zł uzyskiwało 68\% właścicieli ziemskich w województwie oraz że do tej grupy należało 83,6\% majątków leżących w pow. owruckim, co pokazuje skalę zagospodarowania i zamożności tego powiatu. 


\section{$* * *$}

Dominująca formą własności ziemskiej w woj. kijowskim była własność szlachecka, na która przypadało 78,8\% miast i wsi. Wielkość dóbr duchownych i królewskich była podobna, stanowiły one odpowiednio 12,4 i $12,8 \%$ osad. Należy podkreślić znaczny udział wielkiej własności (szlacheckiej, kościelnej, jak i opartej o dzierżawy królewszczyzn) w strukturze własności i strukturze dochodów w woj. kijowskim. W jej rękach znajdowało się $46 \%$ miejscowości i $32 \%$ przychodów. Pod tym względem wyjątkowa postacią był hetman Franciszek Ksawery Branicki, do którego należało $10 \%$ osad przynoszących mu rocznie ponad milion zł, co stanowiło 16,2\% sum uzyskiwanych ze wszystkich majątków w województwie. Częściej jednak lista największych posiadaczy nie pokrywała się z listą osób uzyskujących największy dochód. Wynikało to przede wszystkim ze stanu zagospodarowania majątków. W woj. kijowskim wyraźnie słabiej zagospodarowanym terenem był pow. owrucki, leżący w jego północnej części. Powiat ten charakteryzowała znaczna liczba drobnych osad, takich jak futory i słobody, oraz ponad dwukrotnie niższy średni przychód $\mathrm{z}$ jednej wsi niż w dwóch pozostałych powiatach. $\mathrm{Z}$ tego powodu właściciele ziemscy posiadający tam większe majatki uzyskiwali z nich niewielkie dochody.

Porównanie wielkości majątków z ich dochodowością prowadzi do stwierdzenia zawodności kategoryzowania szlachty pod względem liczby posiadanych wsi. Truizmem jest stwierdzenie, że wieś wsi nierówna. Pomimo tego, ze względu na stan zachowania i elementy treści dostępnych źródeł, liczba posiadanych wsi bardzo często jest i będzie jedynym, choć niedoskonałym, narzędziem umożliwiającym badanie struktury majątkowej szlachty do końca XVIII w.

Badając materiały dotyczące poszczególnych powiatów, ziem i województw, można w miarę dokładnie przedstawić strukturę własności szlacheckiej na danym terenie, pomijając problem szlachty cząstkowej, niezbyt precyzyjnie odnotowywanej w staropolskich rejestrach skarbowych. Nie można jednak przedstawić struktury majątkowej szlachty, zwłaszcza zamożniejszej i magnaterii, często posiadającej dobra leżące $\mathrm{w}$ różnych powiatach i województwach. Jest to niestety sytuacja nie do uniknięcia przy obecnym stanie zachowania materiałów skarbowych - rozproszonych i niekompletnych. Niewatpliwie protokoły „Ofiary 10 i 20 grosza” jako materiał masowy i wytworzony w tym samym czasie sa źródłem umożliwiającym przeprowadzenie badań zakrojonych na szerszą skalę, obejmujących obszar kilku lub więcej województw. 
Konrad Rzemieniecki

Structure of Landed Property and Its Revenues in the Voivodeship of Kiev in 1789

(Summary)

The voivodeship of Kiev was situated in the eastern part of the Commonwealth along the frontier with the Russian Empire. At the end of the eighteenth century its area totalled over $59000 \mathrm{sq}$. km. The dominating form of landed property was the gentry estate, which embraced ca. $78.8 \%$ of all towns and villages. The dimension of royal and Church property was similar and comprised $12,4 \%$ and $12,8 \%$ of all settlements, respectively. Emphasis must be placed on the considerable participation of large estates (gentry, Church, and leased royal estates) within the property and income structure in the voivodeship in question: $46 \%$ of local cities and $32 \%$ of revenues from landed property. In this respect, an exceptional rank was enjoyed by Hetman Franciszek Ksawery Branicki, the owner of $10 \%$ of settlements, with an annual income of over a million zlotys, i.e. $16,2 \%$ of revenues obtained from all estates in the voivodeship. Apart from Branicki, the list of the largest owners did not correspond to that of persons with the most imposing revenues. This state of affairs was the outcome predominantly of the administration of the estates. The northern part of the voivodeship of Kiev (the county of Ovruts) was worse administered and its characteristic feature was a significant number of small settlements and a twice lower income from a single village than in other regions of the voivodeship. Alongside large landed property, the titular voivodeship, and in particular its northern part, was also distinctive for estates-owners of small parts of villages. 